\author{
스타일 형성에 관한 연구 \\ - Iris Van Herpen의 스타일을 중심으로 - \\ 김 영 선 \\ 명지대학교 디자인학부 패션디자인전공 부교수
}

\title{
A Study on the Formation of a Style \\ - Focusing on the Style of Iris Van Herpen -
}

\author{
Kim Yonson \\ Associate Professor, Fashion Design Major, Division of Design, Myongji University
}

\begin{abstract}
This study aims to identify the meaning and formation cause of a style, and the essential elements of style formation, through psychobiological research as well as an analysis of the designs of Iris Van Herpen, a fashion designer, who in just 6 years has developed into a world-renowned new designer.

As a result, it has been found that the psychobiological causes to form a style stem from the action of 'long-term memory', which is consolidated by 'selective attention', 'perceptional subjectivity', the principle of the 'neuron's connection specificity and invariance', and the principle of a 'neuronal signal's unilateral flow'. With such action, Herpen could develop her own original composition techniques. The formative shapes created by such composition techniques are characterized by enumeration, superposition, and hanging.

The study has also found that the essential elements for a designer to be able to form his/her own style include 'aesthetic originality' in which the designer views the property of a thing from his/her inherent perspective, and finds the uniqueness from the thing that only he/she can express, 'technical differences' that are creative and original, and 'formative specificity' that is summarized into one property through an impressive shape.
\end{abstract}

Key Words : Fashion designer(패션 디자이너), Style(스타일), Self-similarity(자기 유사성), Long-term memory(장기 기억), Consolidation(고착화)

corresponding author : Kim Yonson Tel.+82-10-9194-4948, Fax.+82-31-335-4275

E-mail:kiyoso@mju.ac.kr 


\section{I. 서 론}

\section{1. 연구목적}

세계적으로 명성을 얻은 패션 디자이너에게는 여 타 디자이너와는 확연히 구별되는 스타일이 있다. 스타일은 창작을 이끄는 원동력으로서 작용될 뿐만 아니라, 디자인을 창작하는 과정 속에서 어떤 특정 형태나 문양, 색과 소재의 조합 또는 해체나 과장, 중첩, 생략과 같은 창작 요소가 반복적으로 나타나 도록 이끌어 디자이너의 아이덴티티를 구별하게 해 준다.

그리고 세계인에 의해 기억되는 디자이너의 스타 일은 곧 브랜드의 유명세와 경쟁력으로 이어져 패션 시장에서 우위를 점유하게 하는 중요 요인이 되고 있다. 그렇기 때문에 세계 패션 시장에서의 성공은 곧 사람들에게 기억되는 스타일을 어떻게 만들어 내 는가에 달려있다고 할 수 있다. 따라서 스타일의 의 미는 무엇이고 패션디자이너의 스타일이 어떻게 형 성되는지 알아보는 것은 중요한 연구 과제라 할 수 있다.

그러나 스타일은 장기간에 걸친 학습과 체험이 반 복됨으로써 형성되기 때문에 연구 대상의 지속적인 관찰이 필요하고, 또한 인간의 지각과 기억 체계와 깊은 연관을 맺고 있기에 실증적 모델을 제시하기가 어려운 주제이다. 즉 조형적 측면뿐만 아니라 정신 생물학적인 측면의 연구가 병행되어야 비로소 그 형 성 원인을 찾을 수 있는 주제라 할 수 있다.

그래서 그 동안의 스타일에 관한 연구는 이미 형 성된 스타일의 분류나 사회적 형성 원인을 분석하는 형태로 진행되었을 뿐, 정작 스타일의 의미는 무엇 이고, 한 디자이너의 스타일은 어떤 과정과 원인에 의해 형성되며, 스타일이 형성되기 위한 필수 요소 는 무엇인지에 관한 연구는 미흡하였다.

따라서 디자인의 중요성이 부각되고 있는 현대의 산업사회에서 일련의 독창적인 디자인을 만들어내도 록 이끄는 스타일에 관한 연구가 필요하다고 보고 다음과 같은 연구목적을 두었다. 첫째, 스타일의 의 미는 무엇이고, 둘째, 스타일 형성에 영향을 미치는 정신생물학적 원인은 무엇인지 살펴보고자 한다. 셋 째, 한 디자이너의 스타일이 어떤 원리와 과정에 의
하여 형성되는지 그 실증 모델로서 세계적인 신예 디자이너로 부상한 헤르펀(Iris Van Herpen)의 디자 인을 분석하여 제시하고자 한다. 그리고 넷째, 이러 한 분석을 통하여 독창적인 스타일이 형성되기 위한 필수 요소는 무엇인지 살펴보고자 한다.

\section{2. 연구방법 및 내용}

스타일 형성에 관한 연구를 수행하기 위한 연구 방법으로서 먼저 예술 분야 속에서 통용되고 있는 스타일의 의미를 살펴보고, 스타일의 형성과 관련이 있는 인간의 지각 체계와 기억을 형성하게 하는 뉴 런의 메커니즘에 관한 문헌적 고찰을 선행하였다. 그 이유는 장기간에 걸쳐 사물을 지각하고 창작하는 체험이 반복됨으로써 형성되는 창작 성향이 스타일 과 깊은 관계가 있다고 추정하기 때문이다. 그러나 스타일의 형성에 영향을 미치는 선천적인 유전 내용 과 유아기에 경험한 무의식적인 내용은 실증 모델을 제시할 수 없어 연구범위에서 제외하였다.

그리고 이어 최근 컬렉션에서 독창적인 디자인으 로 새로운 스타일을 제시한 한 디자이너를 선정하여 컬렉션에서 표현된 조형적 특성의 반복과 변화의 흐 름을 분석하였다. 분석 대상 디자이너로서 헤르펀을 선정한 이유는 27세의 나이에 2011/12 F/W 파리 오뜨 꾸뛰르(Haute Couture) 컬렉션에 참가하여 세 계에서 가장 주목 받는 신예 디자이너로 각광을 받 고 있고, <그림 1 $>^{1)}$ 과 같이 지금까지 보지 못하였 던 독창적인 스타일을 선보였으며, 또한 2005년 졸 업 작품에서부터 2011년 최근 디자인까지의 모든 컬렉션을 공신력 있는 인터넷 매체를 통하여 확인할 수 있기 때문이다.

헤르펀의 컬렉션에서 반복적으로 드러나는 조형 요소와 창작 기법들을 분석하기 위한 연구범위는 2005년 졸업 작품, 2008년부터 2010년까지의 컬렉 션, 그리고 최근에 발표한 2011/12 F/W H-C 컬렉 션으로 분류하여 살펴보았다. 그리고 이러한 분석 내용을 토대로 스타일이 형성되기 위한 필수 요소는 무엇인지 도출하였다.

이 연구는 세계적으로 촉망받는 신예 디자이너의 스타일이 어떻게 형성되는지 정신생물학적 원인과 조형적 변화를 병행하여 연구해봄으로써, 반복적 지 
각과 체험에 의한 스타일 형성의 필수 요소를 제시 했다는 점에서 연구의 의의가 있다고 할 수 있다.

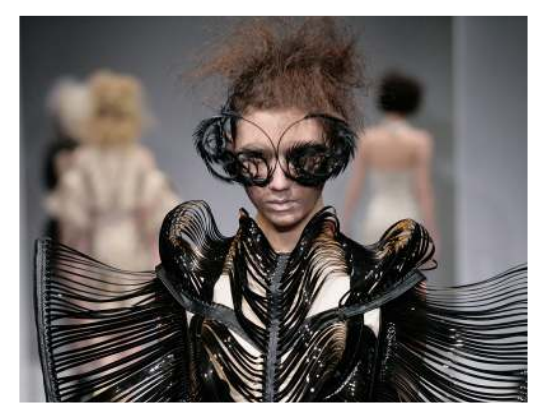

<그림 1> 2011/12 F/W H-C Collection -http://www. irisvanherpen.com/

\section{II. 이론적 고찰}

\section{1. 스타일의 의미}

스타일(Style)은 '자기의 생각을 표현하는 방식 (Manière d'exprimer sa pensée)'을 나타내는 라틴 어 'stilus'에서 유래한 말이다. ${ }^{2)}$ 이러한 의미와 더불 어 어떤 기간이나 지역 혹은 그 나라에서만 고유하 게 나타나는 예술적 경향의 특성을 일컫기도 하고, 또는 어떤 오브제나 사람에게 구별되어 나타나는 고 유한 특성을 지칭하는 용어로도 사용된다. 'stylus' 로도 간혹 표기되지만 이는 건축에서의 기둥을 나타 내는 그리스어 'Stylos'와의 혼용에 의한 잘못된 표 기이다. ${ }^{3)}$

어원적으로 살펴보았을 때 “'stilus'는 고대 로마 시대에 밀랍이 칠해진 판에 필기하기 위해 사용된 상아 또는 금속 막대를 지칭한다. 이 원래의 의미로 부터 그 단어는 개인 문체의 특정 성격으로 확대되 었다. 그것은 후에 한 예술가 또는 학파 내에 인식 될 수 있는 예술적 독특성을 지칭")하는 용어로서 통용되게 되었다.

이러한 사전적 의미를 바탕으로, 예술 분야에서 다양한 스타일을 체험하며 활동하는 전문가들은 각 자의 연구 분야에 적합한 스타일의 의미를 폭 넓게 정의하고 있다. 조형 예술 분야의 평론가 사피로
(Meyer Schapiro: 1904-1996)에 의하면 “스타일에 의해 의미되는 것은 한 개인 또는 집단의 예술에서 일정한 형태-때로는 일정한 요소, 질, 그리고 표현 을 뜻한다. ${ }^{5)}$ 고 하였다.

그리고 언어 예술을 다루는 시인, 예이츠(William Butler Yeats: 1856-1939)는 예술의 패턴을 스타일 이라 말하며, 사사로운 감정에 치우쳐 작가의 비극 적인 싸움이라 할 수 있는 감상에 치닫는 것을 극복 하게 해주는 제어장치로서 역할을 하는 것이 스타일 이라고 하였다. ${ }^{6)}$ 이러한 내적인 정제 과정을 거치며 탄생되는 스타일은 작품이라는 형식 속에 내포되는 작가의 정신을 대변하게 되면서, "프랑스에서는 대 개 19세기 중엽, 영국에서는 19세기 말엽을 분기점 으로 하여 독창적인 스타일이 예술 작품의 주요 평 가기준으로 확립")되었고, 예술가들은 작품 속에 자 기만의 고유한 스타일을 창조해 내는데 전력을 기울 이게 되었다.

스타일은 이러한 후천적인 정제 과정에 의해 선천 적인 기질이 특유의 독자적인 색을 갖게 되면서 탄 생되며, "예술에서 스타일은 예술가의 감수성과 의 식, 세계에 대한 주체의 태도를 드러낸다. 그것은 하나의 심미적 원칙이며, 배치의 규범이기 이전에 예술 창조 주체의 본능이며 기질" ${ }^{\prime \prime)}$ 에 속하는 것으 로, 한 번 형성되기 시작되면 그 특색은 일관성을 갖게 된다.

이는 마치 “시간 스케일(Scale)이 변해도 변화 패 턴이 동일한 현상” ${ }^{9}$ 을 나타내는 자기 유사성 (self-similarity)과 같아서 하늘에서 떨어지는 눈이나 나뭇가지, 손의 지문, 강의 줄기 등에서처럼 동일한 기본적 요소가 여러 해, 여러 작품에 걸쳐 반복적으 로 나타난다. 자기유사성은 "카오스(Chaos) 연구의 대가인 베노이트 맨들브로트(Benoit Mandelbrot)가 1975년 발견하였던 새로운 차원의 모양인 프랙털 (fractal, 次元分裂 圖形) 구조의 기본 성질을 나타내 는 용어이다." ${ }^{10)}$

스타일 형성과 관련을 갖는 '자기유사성'이란 “선 택성된 신경 세포를 갖고 태어나는 선천적인 원인과 주어진 환경에 적응하면서 겪는 후천적인 원인에 의 해 형성되어 반복적으로 나타나는 성질을 의미한 다." ${ }^{11)}$ 이러한 성질에 의해 디자이너의 창작 과정에 
는 어떤 특정 색상이나 소재, 형태, 창작 기법 등이 반복적으로 나타나게 되기에 '자기유사성'은 스타일 을 형성하게 하는 기본 성질이라 할 수 있다.

예술, 문학, 디자인 등의 창작 분야에서 추구되는 작가의 독창적인 스타일은 "대중예술의 도식성에 생 생함을 주고, 대중예술의 자극성에 정교함" ${ }^{22}$ 을 주 는 역할을 하면서 "일상적인 것을 비상한 것으로, 평범한 날을 축제일로, 일상적인 삶을 높은 수준으 로 끌어올리는 요소” ${ }^{13)}$ 로도 작용되며 “힘과 기쁨의 원천으로 생각하여 소모되지 않는 에너지” ${ }^{\prime 4)}$ 로도 표 현되고 있다.

이처럼 스타일이 갖는 다양한 의미가 있지만 이 연구에서 다루고자 하는 스타일이란 선천적인 기질 과 후천적 성향의 영향에 의해 반복적으로 디자인에 나타나는 디자이너의 독자적인 조형적 특색으로서, 디자이너의 미적 관점, 제작 기법, 디자인 형태에 의해 표출되는 고유한 특성을 의미한다.

\section{2. 스타일 형성의 정신생물학적 원인}

디자이너의 스타일은 창작 과정 중에 표현되는 디 자인의 형태, 재질, 문양, 배색, 창작 기법에 따른 효과 등과 같은 조형적 요소에 의해 드러난다. 그리 고 이러한 요소들은 디자이너의 기질과 창작 성향에 의해 선택되며, 기질과 성향은 선천적 요인과 사물 을 지각하고 반복적으로 창작하는 후천적 체험이 축 적됨으로써 형성된다.

“임마누엘 칸트는 우리가 특정한 앎의 틀을 내장 하고 태어난다고 주장했다. 칸트가 선험적 지식이라 고 부른 그 틀은 감각 경험을 수용하고 해석하는 방 식을 결정” ${ }^{15}$ 한다고 하였다. 이처럼 기질과 성향은 선천적인 요인에 기인한다는 칸트의 견해에 반하여, 경험론자인 존 로크(John Locke)와 데이비드 흠 (David Hume)은 연습이 완벽함을 만든다며 후천적 인 영향을 중시하였다. 유전론자들은 " $\mathrm{QQ}$ 의 유전율 은 75 85퍼센트이며 환경 요인이 기여하는 정도는 15 25퍼센트" ${ }^{" 16)}$ 라고 주장하고 있고, 기억 과정을 밝힌 공로로 2000년 노벨상을 수상한 에릭 캔들 (Eric R. Kandel)은 이러한 선험적 지식과 후천적 경험이 상호보완적이라는 사실을 실험을 통하여 입 증하면서 “신경 회로 속 특정 연결들의 세기 변화는
경험의 영향을 반영”하고, “기억의 기반에는 그런 세기 변화의 지속성이 있다." ${ }^{177}$ 고 하였다. 이는 반복 적으로 경험한 내용이 신경 회로를 통하여 기억에 지속적으로 축적되어 장기 기억으로 저장되므로 기 질과 성향이 후천적 영향을 받게 된다는 의미이다.

정신생물학에서의 신경 메커니즘 연구에 의하면 인간의 장기 기억은 최대 2년이 소요되는 과정 속에 서 형성된다. ${ }^{18)}$ 성향이란 습관처럼 장기 기억에 저 장됨으로써 나타나는 특성이기에 스타일 또한 장기 기억의 영향에 의해 나타나는 것이라 할 수 있고, 이러한 스타일이 한 디자이너에게 형성되기 위해서 는 짧게는 3 4년에서부터 길게는 몇 십 년이 소요 되기도 한다.

지금까지 살펴본 바와 같이 디자이너의 스타일은 선천적 기질과 후천적 성향의 영향으로 독자적인 조 형적 특색이 창작 과정 중에 반복적으로 드러나 일 정한 패턴을 나타내는 자기유사성에 의해 형성되며, 이러한 성향이 형성되게 하는 지각 체계와 뉴런의 메커니즘에는 선택적 주의집중, 지각의 주관성, 뉴 런의 연결 특이성과 불변성, 신호의 일방흐름 원리 가 있다.

1) 선택적 주의집중

디자이너의 스타일이 어떤 특정한 형태, 색상, 소 재, 창작 기법에 의한 조화 등과 같은 조형 요소에 의해 나타나는 예술적 독특성, 고유한 특색임을 감 안할 때 스타일이 어떻게 형성되는지 그 요인을 파 악한다는 것은, 스타일 속에 나타나는 그 특별함이 어떻게 형성되는지를 아는 문제라 할 수 있고, 그 문제는 인간이 사물을 바라보는 지각 태도에 기인한 다.

“사람은 시야에 펼쳐진 전체의 대상 중에 관심이 있거나 자극을 주는 특정한 대상을 선택해서 집중한 다." ${ }^{19)}$ 관심을 그는 대상은 지속적으로 기억에 저장 된 내용과 체계적으로 연결된 것들이다. 이러한 대 상들이 시야에 나타나면 집중해서 의식적으로 지각 하게 된다. 이와는 다르게 모양이 특이하거나 갑자 기 소리가 나는 등 대상에서 드러나는 특별함이 감 각 기관을 자극하는 경우에도 대상에 집중하게 된 다. "그래서 주의집중이란 자기에게 관심 있는 자극 
에 집중하기 위해 다른 것들로부터 물러나는 것을 의미한다." ${ }^{20)}$ 이때 지각된 내용이 이미 기억에 저장 된 내용과 연관이 있으면 그 내용과 함께 새로운 체 계를 이루게 되고 그렇지 않으면 그 내용은 무시되 어 점차 기억 속에서 사라진다. 이처럼 "사람들은 임의의 순간에 환경으로부터 무수한 감각 자극을 받 지만 하나 또는 그와 관련된 몇 개 사항에만 선택적 으로 주의를 기울이고 나머지는 무시하거나 억압해 버린다." ${ }^{21)}$

영국의 생리학자 찰스 셰링턴(Charles Scott Sherrington)은 이러한 선택적 주의집중이 일어나는 원인을 "억제뉴런들이 하나의 반사만 남기고 나머지 반사들을 억제함으로써 특정 자극에 대하여 안정적 이고 예측 가능하며 협응된 반사가 일어나도록 만든 다."며 이 신경 메커니즘을 “상호적 통제(reciprocal control)" ${ }^{22}$ 라 명명하였다. 이와 같은 지각 체계의 원리에 의해 디자이너는 자기의 기억과 관련된 형 태, 색상, 소재 등을 선택하여 집중하게 된다. 이렇 게 집중하여 지각한 내용들이 축적되어 장기 기억에 저장되고, 또 다른 새로운 대상을 선택적으로 지각 하게 이끈다. 이러한 이유로 기억 작용이란 체계적 인 연결의 연속이라 할 수 있고, 이렇게 체계적으로 입력된 기억의 내용이 창작 과정에서 조형 형태로 표현되기에 디자인의 일련성을 갖게 된다.

\section{2) 지각의 주관성}

"지각한다는 것은 우주의 대상 전체 중에 자극을 주거나 관심이 있는 것을 선택해서, 그 선택된 것의 전체가 아닌 일부의 어떤 것에 집중하는 것을 의미 한다. 그리고 집중하여 지각한 내용은 기억의 일부 로 저장되고, 이러한 단편적인 지각 작용에 의해 수 용된 내용들이 축적되어 기억의 전체를 이룬다." ${ }^{23)}$

그래서 기억의 대부분은 자기중심적인 스스로의 관심과 필요에 따라 주관적으로 수용한 단편적인 내 용으로 구성되어 있고 ${ }^{24)}$, 그 내용에 의해 또 다른 대상을 실재적이기보다는 실용적으로 지각하는 반복 이 이루어진다. 그래서 대상이 아무리 사전적 의미 에서의 실재성을 갖고 있다 해도, 인간은 자기의 용 도에 맞게 지각하고 다르게 해석하는 주관성을 갖고 있다.
이러한 이유로 대상에 대한 하나의 사실이라는 것 은 "사람의 직관에 직접 주어진 것들이라기보다는 변질되거나 탐구된 경험, 인위적으로 재구성된 경 험”25) 이라 할 수 있다. 그렇기 때문에 “기술적인 이해가 상상력을 통해서 발전”26)할 수 있는 것이고, 창작 과정 속에서 독창적 기법이 드러날 수 있게 된 다.

그래서 디자이너는 이러한 지각의 주관성에 의해 자기가 경험한 색상, 소재, 창작 방법 등에만 관심 을 갖게 되고, 새로운 대상을 접하여도 기억된 내용 과의 주관적인 관련성을 찾게 된다.

3) 뉴런의 연결 특이성/ 불변성/ 일방흐름 원리 독일의 생물학자 프란츠 요제프 갈(Franz Joseph Gall: 1758-1828)은 특정한 정신 능력이 피질의 특 정 영역에 위치하는 사실을 발견하였고 ${ }^{27)}$, "후대에 이르러 외부의 감각 자극이 정해진 신경 경로를 통 해 뇌의 정해진 목적지에 운반된다는 사실이 실험을 통하여 입증되었다." ${ }^{28)}$

그리고 이어 스페인 생리학자 카할(Santiago Ramón y Cajal: 1852-1934)은 "신경 세포는 특정 한 세포들끼리 서로 소통한다는 사실” 과 “신경 세포 들은 '연결 특이성 원리'를 통해서 신경 회로를 이 루고 신호들은 그 회로들을 따라서 예측 가능한 패 턴으로 이동한다는 사실"을 발견하였다. 또한 “뉴런 회로 속의 신호가 오직 한 방향으로만 이동한다는 사실”이 추가로 확인되었다. ${ }^{29)}$ 이와 같은 “신경 세 포의 불변성은 기억이 저장될 수 있는 이유와 다시 상기될 수 있는 근거로 작용되고 있다." ${ }^{30}$

어떤 색이나 소재 또는 형태를 한 번 접하여 기억 하게 되면 그와 관련된 모든 내용은 특이하게도 뉴 런의 일정한 회로를 통하여 뇌에 전달되기 때문에 시간이 흐른 후에도 기억할 수 있게 되고 반복적인 회상을 가능하게 한다.

“뛰어난 장인은 누구나 구체적인 작업과 생각 사 이를 오가는 대화를 하게 되고, 이 대화는 반복적인 습관으로 진화"1)되는 것처럼, 지각과 기억의 체계 는 작업 과정에도 그대로 적용되어 디자인 형태에 영향을 미치게 된다. 이러한 메커니즘을 바탕으로 학습이 이루어지고, 반복적인 지각과 기억 작용에 
의해 입력된 정보가 기존의 기억 내용과 체계적으로 연결되어 저장될 때 기억의 고착화가 발생되어 장기 기억이 형성된다. ${ }^{32)}$

고착화(固着化, consolidation)란 “반복적 체험이 나 사건의 충격과 같은 내용이 장기 기억으로 굳어 져 지속되는 것을 말하며 또한 디자이너의 스타일이 형성되게 작용하는 기억의 메커니즘을 의미" ${ }^{33)}$ 한다.

이와 같이 스타일은 <그림 2>에서처럼 선천적 지 각 체계에 기인하는 선택적 주의집중, 지각의 주관 성, 뉴런의 연결 특이성/불변성/일방흐름 원리의 영 향에 의해 관심을 끄는 대상만 지속적으로 기억하 고, 대상을 실재적이기 보다는 실용적으로 지각하며, 입력된 정보가 체계적으로 기억의 내용과 연결되어 고착화됨으로써 나타나는 자기유사성에 의해 형성된 다.

\section{Herpen의 디자인 분석}

헤르펀은 1984년 네덜란드의 바멜(Wamel)에서 태어나 아른헴(Arnhem)의 ArtEZ 종합예술대학교에 서 패션디자인을 전공하여 2005년 졸업하였고, 2006년 맥퀸(Alexander McQueen)의 디자인실에서 인턴을 한 경험이 있으며,, ${ }^{34)}$ 2011년 1월 파리 오뜨 꾸뛰르 컬렉션에 참가하여 각광을 받은 신예 디자이 너이다.

오랜 역사적 전통과 기술, 그리고 막대한 자금력 과 전문 인력을 앞세워 세계의 패션 산업을 장악하
고 있는 거대한 기업과 유명 디자이너 브랜드의 유 명세에 대항하며, 패션 역사에서 한 번도 시도되지 않았던 창의적인 디자인을 지속적으로 발표함으로써 새로운 스타일을 창조한 헤르펀은 패션계에 입문하 는 젊은 디자이너가 지향해야 할 방향과 창작성의 중요성을 잘 보여주었다.

따라서 이처럼 세계계적인 명성을 얻게 한 디자인 의 특성과 독창적인 스타일이 어떻게 형성되었는지 분석하기 위하여 헤르펀의 디자인을 수집하였고, 분 석을 위한 시대적 구분은 2005년의 졸업 작품 <표 1>35), 2007년 7월 암스테르담의 2008 S/S 패션 위 크 기간에 '연약한 미래(Fragile Futurity)'라는 주제 로 발표한 첫 컬렉션에서부터 2010년까지의 컬렉션 <표 2>36), 그리고 2011년 1월 파리에서 최근 발표 한 2011/12 F/W H-C 컬렉션 <표 3>37)으로 분류하 였다. 그리고 디자인 분석은 소재, 색상, 창작 기법 에 표현된 특징으로 나누어 실시하였다.

\section{2005 졸업 작품}

헤르펀의 졸업 작품에는 일반적 방식과 구별되게 옷을 디자인하고 만들어내는 특유한 생각과 창작 기 법이 드러나 있다. 패션디자인을 창작한다는 것은 다양한 방법을 활용하여 평면적인 소재를 입체적인 인체에 어떻게 감싸는가 하는 문제로 귀결된다. 그 대표적인 방법으로서 인체의 특징을 패턴화하여 면 을 분할하고 조합하는 구성 방법이 있다. 이때 면을 나누는 형태, 절개선의 위치, 품의 분량 등을 고려 하게 된다. 옷의 형태는 인체의 움직임에 순응하는

\section{스타일 형성 흐름도}

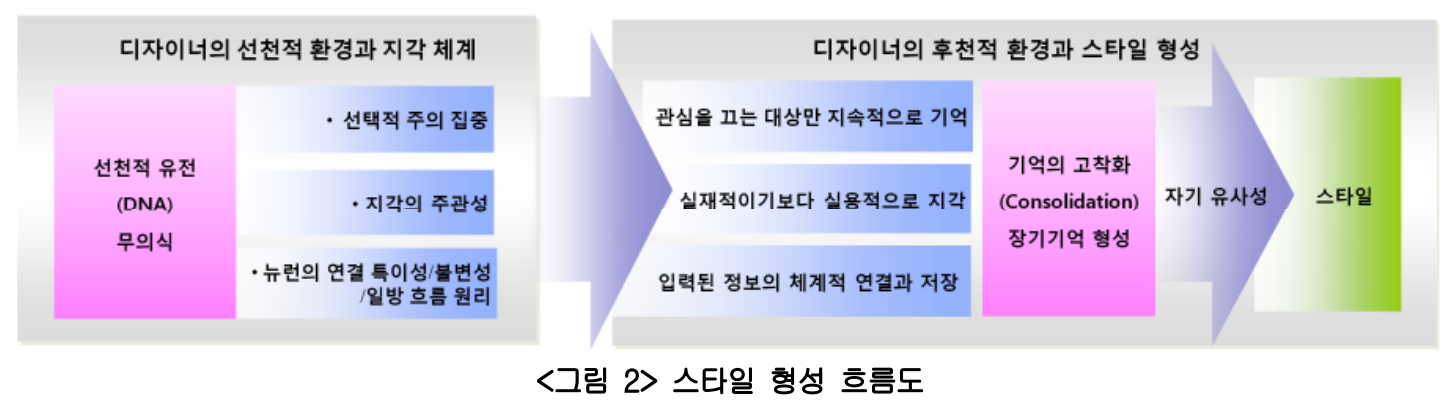


기능을 염두에 두어야 하기 때문이다.

디자인이 갖는 조형적 형태의 아름다움을 기능의 부산물로 파악했던 미국의 건축가이며 미술이론가였 던 그리노(Horatio Greenough: 1805-1852)는 “형 태는 기능을 따른다(Form follows function)." ${ }^{38)}$ 며 기능에 순응되는 형태의 중요성을 추구하여 모더니 즘 시대의 디자인에 많은 영향을 미쳤다. 현대에 이 르러서는 융합과 통섭이라는 형태로 새로운 디자인 이 개발되면서부터 형태와 기능이 갖는 상관관계의 중요성이 감소되었지만, 사물 본래의 기능에 따른 디자인의 형태가 갖는 중요성은 디자인 창작에 아직 도 유효하다.

헤르펀은 <표 1>에서처럼 졸업 작품을 통하여 고 전적인 의복구성 기술에 의한 디자인 창작을 최소화 하고 그 대신에 소재를 엮거나 겹쳐서 늘어트려 인 체를 장식하는 공예적인 창작 기법을 택함으로써 옷 의 기능적 제약을 해결함과 동시에 형태도 새로운 디자인을 선보였다.

같은 해 졸업 작품을 발표한 동료들의 디자인들은 대부분 면을 이용한 의복구성 방법에 의해 제작되었 음을 미루어 볼 때, 헤르펀 역시 의복구성에 관한 지식은 습득했으리라 사료된다. 그러나 헤르펀은 패
턴의 논리와 기술적 구속에서 벗어난 다른 구성 방 법을 택함으로써, 비율이나 균형, 대칭성에서 벗어 난 비완성적인 디자인, 탈 패턴화된 디자인을 제시 한 것이다.

이러한 시도를 통하여 헤르펀은 창작 기법에서의 고유한 색을 드러낼 수 있었다. 끈, 넓은 밴드, 술, 가죽 띠와 같은 소재와 카키, 그레이, 블랙, 오프 화 이트 등의 무채색만을 사용하여 소재를 엮거나 중첩 시켜 늘어트리고, 밴드를 나열하여 이음으로써 정형 화된 패턴에서 탈피하였고, 때로는 의식적으로 신체 를 과장하는 조형적 특징을 나타낸 것이다.

\section{2008-2010 컬렉션}

헤르펀이 졸업 작품 이후 암스테르담의 패션 위크 에서 첫 컬렉션을 발표한 2008 S/S부터 2010년까 지의 디자인을 분석한 결과, <표 2>에서처럼 졸업 작품에서 볼 수 있었던 끈, 술, 밴드 등의 소재와 함께 얇은 밴드 형태로 잘라도 올이 안 풀리는 비닐 과 가죽 그리고 오간자(Organza) 소재가 같은 맥락 으로 사용되었고, 베이지, 브론즈계 색상이 추가된 무채색의 사용이 지속되었음을 알 수 있었다.

<표 1> 헤르펀의 2005년 졸업 작품

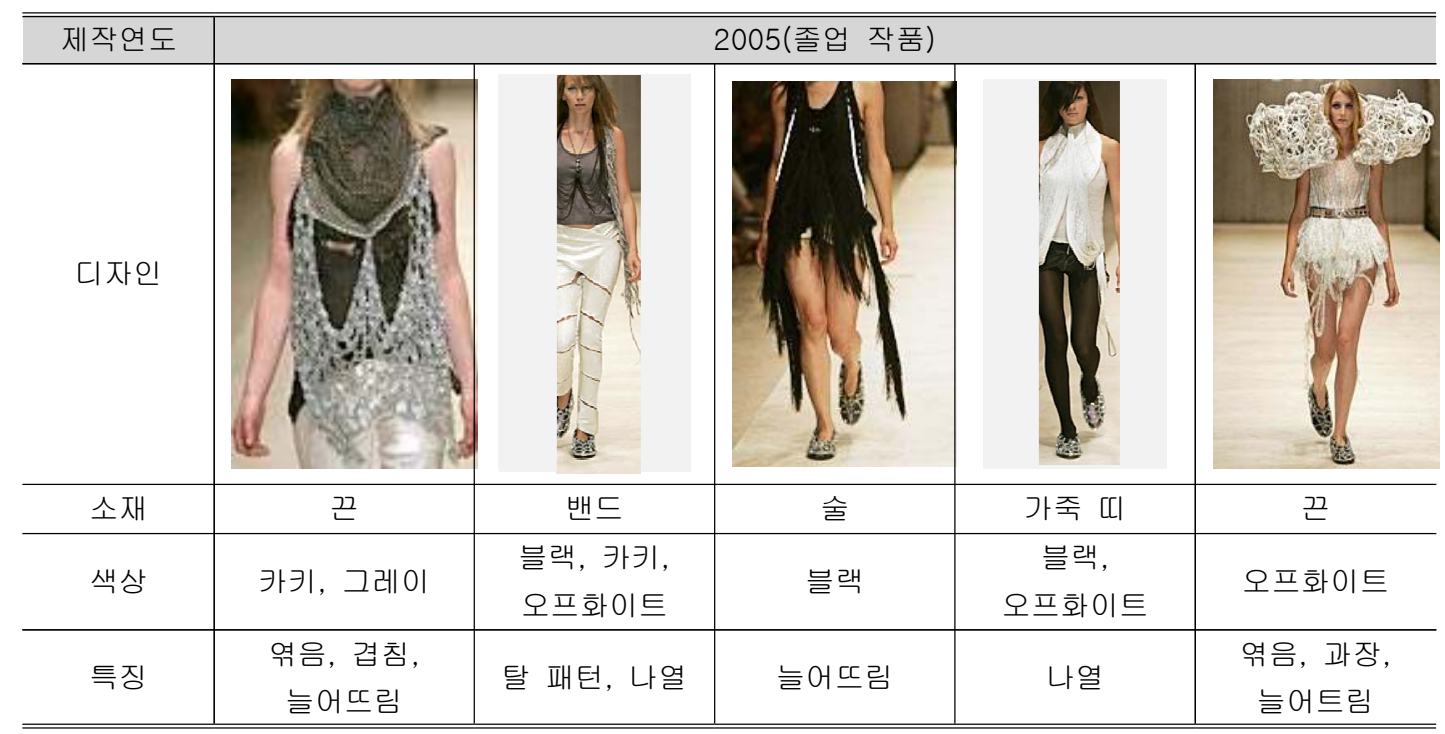

-http://www.modearnhem.nl/ 
이와 더불어 엮거나 겹쳐 늘어트리고, 밴드를 나 열하여 잇는 탈 패턴 창작 기법과 그 기법에 의해 나타나는 조형적 특징도 지속되었다. 다만 끈이 엉 키듯 엮임으로써 형성되던 거칠고 둥근 볼륨이 오간 자 소재에 의해 부풀려져 가벼우면서 부드러워졌을 뿐이다.

이처럼 졸업 작품을 발표한 이후부터 다섯 해에 걸쳐 헤르펀에게는 일련의 소재와 색상을 유사한 기 법으로 다루는 체험이 반복되었고, 그 결과 한 특색 으로 요약될 수 있는 창작 성향이 드러남을 알 수 있다. 앞에서 살펴본 바와 같이 디자이너의 스타일 이란 어떤 특정한 형태, 색상, 소재, 창작 기법 등에 의해 조형적으로 나타나는 예술적 독특성, 고유한 특색임을 감안할 때, 헤르펀에게는 일반적인 패턴 구성 방법에서 벗어나 탈정형화를 통한 새로운 형태 를 추구하는 탐험적인 성향의 스타일이 형성되었음 을 알 수 있다.

이는 관심 대상을 선택적으로 집중하여 주관적으 로 해석하고, 그 체험 내용이 지속적으로 반복되어 뉴런의 기억 메커니즘에 의해 장기 기억에 저장되 고, 또한 고착화된 장기 기억이 작업 방향과 선택에 지속적으로 관여하기 때문에 가능한 일이다.

\section{3. $2011 / 12$ F/W H-C 컬렉션}

헤르펀은 졸업 작품을 발표한 지 불과 6년 후인 2011년 파리 컬렉션에서 어느 누구도 쉽게 모방할 수 없는 창작 개념과 창의적 제작 기술에 의한 독보 적인 조형 형태를 선보였다. 이 컬렉션에도 그동안 헤르펀이 주로 사용하였던 밴드, 비닐, 가죽 소재와 무채색이 주는 농담의 변화가 지속되어 나타났다. 그러나 이러한 조형 요소를 다루는 기법에 괄목할만 한 성장이 있었음을 알리는 다양한 전위적 디자인 형태가 드러나 있었다. 이는 신체와 옷이라는 두 요 소의 상관관계에 의해 구속되던 제작 방법의 제약들 이 헤르펀의 엮고 덧붙이는 공예적 창작 기법에 의 해 제거되어 전례 없는 형태로 표출된 것이라 할 수 있다.

그 내용을 살펴보면 <표 3>과 같이 밴드의 나열 과 와이어에 엮어 만든 입체, 곡선의 가죽 밴드와 끈을 엮어 장식한 탈 패턴적인 구성, 비닐 조각을 중첩시키며 늘어뜨린 입체, '3-D-PRINT' (프린트하 듯 문양을 찍고 난 후 열을 가해 입체 형태로 만드 는 프린트 기법 $)^{39)}$, 오간자를 뭉쳐 만든 과장 형태 등 그동안 반복 체험에 의해 축적된 기술이 총체적

<표 2> 헤르펀의 디자인 변화(2008-2010 Collection)

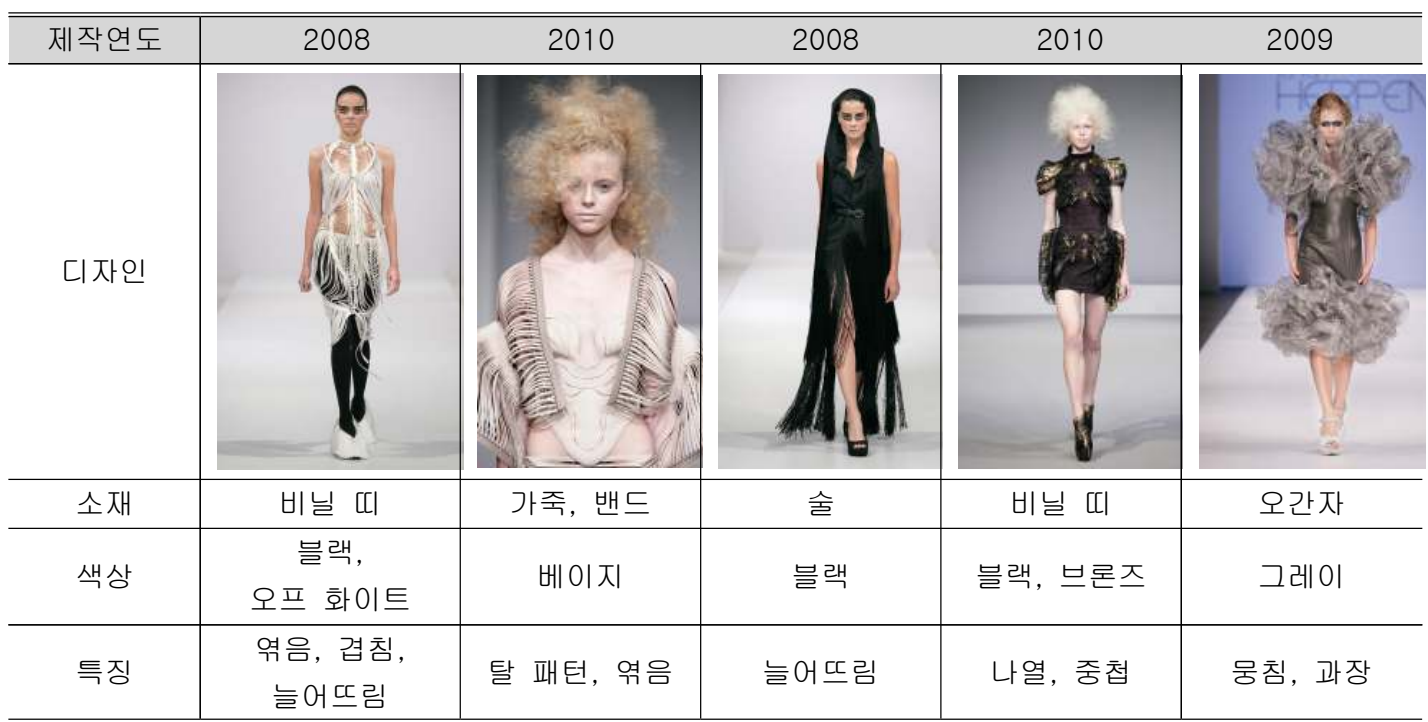

-http://www.irisvanherpen.com/ 
<표 3> 헤르펀의 최근 디자인(2011/12 F/W Paris Haute Couture Collection)

\begin{tabular}{c|c|c|c|c}
\hline \hline 제작연도 & \multicolumn{3}{|c}{ 2011년 } \\
\hline
\end{tabular}

-http://www.vogue.fr/defiles/couture

으로 투영되어 있다. 헤르펀은 이러한 창작 기법을 통하여 신체를 감싸는 옷에 대한 개념과 제작 하는 기법, 옷을 통해 드러나는 인체와 그것을 통한 여성 미를 새로운 형태로 제시하였다고 할 수 있다.

이처럼 헤르펀은 일련의 소재와 색상을 지속적으 로 사용하며 자기만의 특유한 창작 기법을 개발하였 고, 이러한 독창적인 기법에 의해 탄생된 조형 형태 는 헤르펀의 스타일을 대변하는 매체로서 상징성을 갖게 되었음을 알 수 있다.

\section{IV. 스타일 형성의 필수 요소}

지금까지 살펴본 바와 같이 스타일은 자기에게 관 심이 있는 대상만을 선택적으로 집중하고 주관적으 로 해석하는 반복적 체험에 의해 저장된 장기 기억 의 영향에 의해 형성된다. 그리고 고착화되어 저장 된 이러한 내용이 디자이너의 창작 과정에 항상 개 입하여 작업의 방향을 조종하기에 그 영향으로 결과 물에는 일련의 조형적 특색이 나타난다. 그리하여 스타일은 디자이너의 이름과 함께 시공간 속에서 구 별되는 인식의 대상으로 자리매김 되고, 스타일이 강하게 드러나는 디자인은 사회가 부여하는 의미와
더불어 특권적 위치를 점유하게 된다.

인식되는 스타일을 만들어 내는 디자이너는 예술 가와 더불어 "내면적 필연의 목소리에 귀를 기울이 면서 자신과 세계를 창조하는 대표적인 사람" ${ }^{40}$ 으로 서 평범한 사물을 비범하게 생각하고 관찰하는 태도 를 띤다. 그럼으로써 사물과 자기만의 특별한 관계 를 만들고, 그것으로부터 연유되는 즐거움과 아름다 움을 자기만의 미적 관점과 창작 기법에 의한 특이 한 형태로 표현한다. 자기유사성과 같이 그 형태들 에서 드러나는 일련의 특색이 곧 스타일을 대변하는 것이다.

따라서 창작을 하는 디자이너에게 스타일이 형성 되기 위한 필수 요소란 사물이 갖고 있는 특성을 고 유한 시각으로 바라보고 그 대상에서 아름다움을 찾 는 '심미적 독창성', 그것을 자기만의 표현 방법으로 창작해내는 '기술적 차별성', 그리고 그 결과로서 드 러나는 형태가 인상적인 ‘조형적 특이성'이라고 할 수 있다.

\section{1. 심미적 독창성}

디자이너의 스타일을 형성하게 하는 필수 요소로 서 ‘심미적 독창성'이란 창작의 발단에 영향을 미치 
는 심미안적 독특함을 의미하는 것으로서, 발상, 소 재의 물성에 관한 해석, 형태의 조화, 표현의 구상 능력 등에 영향을 미치는 독창성을 의미한다.

사물을 선택하고 그 사물에 맞는 창작을 구상하는 독창적인 혜안과 능력을 의미하는 이 심미적 독창성 은 기술을 개발할 때도, 그리고 디자인 형태를 만들 어 낼 때도 지속적으로 영향을 미치는 창작의 근원 적인 요소로 작용된다.

세상에 펼쳐있는 사물에는 본래의 실재적 의미와 용도가 있지만, 창작자는 실용성에 의해 그 사물의 의미와 용도를 자기가 필요한 내용으로 재해석한다. 그리고 눈앞에 펼쳐있는 수많은 소재 중에 자기의 창작 의도에 소용되는 소재를 선택적으로 관찰하여 독자적인 미적 관점으로 그 대상과 특별한 관계를 만들고, 거기에서 자기만이 표현할 수 있는 특별함 을 찾는다. 이러한 지각 체계의 반복 속에서 심미적 독창성이 형성된다.

그래서 "작품이나 작가의 개별성, 독창성 그 자체 가 다른 많은 작품과 작가들과의 경쟁에서 살아남을 수 있도록 보장하는 우선적인 요건” ${ }^{411}$ 이라 하였듯 이, 다른 수많은 유사성에 의해 대비되는 독창성은 창작의 중요 요소로서 작용된다.

이러한 관점에서 볼 때 헤르펀의 스타일 형성은 여타 디자이너들이 잘 사용하지 않는 띠, 술, 비닐 끈, 가죽 띠와 같은 소재를 선택할 수 있는 혜안이 있었고, 그 소재에 적합한 엮음, 나열, 늘어뜨림 등 과 같은 독창적인 창작 기법을 구상할 수 있는 심미 적 독창성이 있었기에 가능하였다.

그리고 독창적인 심미안으로 소재를 선택하고 기 법을 응용하는 창작을 지속하고 있고, 신체의 움직 임에 따라 트인 틈으로 다르게 투영되는 여성의 독 특한 아름다움을 찾아 표현하고 있기에 헤르펀에게 는 디자인을 표현하는데 있어서 심미적인 독창성을 갖고 있다고 할 수 있다.

그리고 "예술은 나날이 느끼고 생각하며 경험하는 것을 다시 수립하고 농축하고 변형시킴으로써 기존 의 모델을 교정하고 보충하며, 파악할 수 없는 일시 적인 것을 지속적인 것이 되도록 돕는다." ${ }^{22)}$ 는 사실 을 상기하여 볼 때, 헤르펀은 타인과 구별되는 심미 안을 갖고 졸업 작품에서 보였던 내용을 교정하고 보충하는 체험을 반복함으로써 예술의 경지에 다다
른 조각 형태의 디자인을 제시할 수 있었고, 그 것 이 지속되어 타인과 구별되는 특유의 스타일을 나타 낼 수 있었다.

지금까지 살펴본 바와 같이 헤르펀은 열린 틈으로 투영되어 드러나는 여성미를 자기표현의 수단으로 삼아 새로운 스타일을 만들어 낸 디자이너로서의 의 미를 갖게 되었고, 이러한 결과의 배후에서 심미적 인 독창성은 작업의 방향을 이끄는 스타일 형성의 필수 요소로 작용되었음을 알 수 있다.

\section{2. 기술적 차별성}

기술적 차별성은 창작 과정 중에 드러나는 소재의 이용 방법, 패턴의 재단 방법, 볼륨을 만들어 내는 기법 등과 같이 옷을 제작하는 기술적인 면에서 여 타 디자이너와 다르게 나타나는 제작 기법의 유별함 을 의미한다. 이러한 기술적 차별성을 갖기 위하여 심미적인 독창성이 저변에서 작용되어야 가능하다.

새로운 디자인을 창작하는 방법이 시대 속에서 진 부하게 여겨지는 봉제 기술과 재단 기법에 의해 완 성된다면 그 디자인은 과거를 조영함과 동시에 진부 한 스타일을 표상하게 된다. 그래서 어떤 스타일은 시대의 흐름에 밀려 역사의 흔적만을 조명하는 반 면, 어떤 스타일은 옷을 제작하는 기술적 차별성에 힘입어 장기간 유지되어 시대의 유행을 이끌기도 한 다.

따라서 새로운 스타일이 형성되고 유지되기 위해 서는 디자인을 만들어 내는 기술과 기법에 있어서 새로움과 특별함이 있는 기술적인 차별성이 필요하 다. 차별성은 유사성에 의해 드러나는 상대적인 특 성으로서 다수에게 공통적으로 드러나는 것과 다른 특별함을 의미한다.

이런 의미에서 볼 때 헤르펀은 졸업 작품에서부터 파리 컬렉션까지 끈이나 밴드 같은 얇은 소재를 엮 거나 병치시켜 독특한 입체 구조를 만드는 특별한 기술을 지속적으로 선보이고 있기에 기술적인 차별 성이 있다고 할 수 있다. 이러한 기술은 물질과 도 구의 이해와 의복구성을 통한 기본적인 제작 방법을 습득하고 난 후에나 응용할 수 있는 기술이다. 패턴 의 크기를 수치로 계산하고 그 넓이만큼의 가죽 밴 드를 필요 수량만큼 나열하거나 필요 횟수만큼 끈을 
엮는 방식으로 제작되기 때문이다.

헤르펀은 정규적인 대학 과정에서 패션디자인과 의복구성에 관하여 학습하였으므로 전공 분야에 관 한 기본 지식을 교육을 통하여 습득하였다고 추측할 수 있다. 패션디자인에서 기본 지식이란 그림으로 표현한 디자인을 소재를 이용하여 옷으로 만들어 내 는 지식을 의미하는 것으로, 디자인의 구상에서부터 의복구성이란 기술을 통하여 몸의 치수에 맞게 제작 한 여러 패턴을 이어 봉제함으로서 옷이 완성되는 전체 과정까지를 안다는 의미이다.

헤르펀이 이러한 기본 지식을 바탕으로 하여 독창 적이고 특별한 기술을 습득할 수 있었던 이유는, 수 치를 선천적으로 인지하는 직관산(直觀算, subitizing ${ }^{43}$ 이 작용되었기 때문이다. 하나의 패턴에 해당하는 면적을 가죽 밴드나 띠와 같은 다양한 대 체물로 전환하여 수치화하였고, 지각의 주관성을 바 탕으로 한 상상력을 통하여 제작 기법을 편향적으로 발전시켰기에 기술적인 차별화가 발생된 것이다. 이 러한 후천적인 학습 체험이 고착화되어 장기 기억에 저장되고, 장기 기억은 이와 관련된 기술적 내용을 선택적으로 지각하도록 이끌며 아울러 작업의 방향 을 조정하기에 기술적 차별성은 더욱 더 성격을 강 하게 드러낸다고 할 수 있다.

지금까지 헤르펀의 창작 과정을 통하여 살펴본 바 와 같이 창의적인 형태는 그 것을 만들어내는 독창 적인 기술에 의해 완성되기 때문에, 기술적 차별성 이 수반되어야 결국 스타일이 형성된다고 할 수 있 다.

\section{3. 조형적 특이성}

조형적 특이성은 심미적 독창성에 의해 구상되고 기술적 차별성에 의해 창작되어 결과적으로 실루엣, 볼륨, 조화 등으로 표현되어 나타나는 조형적 특별 함을 의미하는 것으로, 일련성을 띠는 이질감이 내 재되는 특징을 갖는다.

현대미술과 더불어 시대의 흐름을 가장 빨리 조영 하는 패션디자인 분야에서 디자이너에 의해 표현되 는 새로움이란 소재와 색의 조화 그리고 여러 창작 방법에 의한 형태의 특이함을 의미한다. 디자이너의 생각은 이러한 조형 요소를 응용하여 제작한 특이한
형태를 통해서 표현되고, 수많은 디자인 속에서 드 러나는 이 형태가 주는 인상의 강도에 따라 디자이 너의 존재감도 비례되기에 디자이너는 차별되는 기 술에 의한 인상적인 형태를 만들기 위해 노력한다.

디자인의 새로운 형태는 관찰자가 선택적으로 대 상을 주의하여 집중하도록 이끌고 흥미를 유발시키 기에 기억될 가능성을 높이는 요소라 할 수 있다. 이를 통하여 디자이너나 브랜드의 이름도 함께 기억 되는 요인으로 작용되기에 디자이너들은 차별되는 기술에 의한 특이한 디자인 형태를 추구하게 된다.

<표3>에서처럼 헤르펀은 일반적인 의복구성에 의 한 창작에서는 볼 수 없는 특이한 디자인 형태를 추 구하고 있다. 소재 본래의 성질을 탐구하여 올이 풀 리지 않는 가죽이나 비닐은 얇게 잘라 묵거나 엮어 면을 만들고, 비닐 조각을 기하 형태로 중첩시키거 나 열을 가함으로써 파랑상의 굴곡을 지어내기도 하 며, 올이 풀리는 오간자와 같은 얇은 소재는 구겨서 뭉쳐 둥근 형태를 만들어 내기도 한다. 그리고 소재 의 탄성을 계산하여 중력의 지배를 받지 않도록 형 태를 만들어 허공에 띄우거나, 와이어나 탄성고무 같은 부차적인 구조물을 활용하여 본래 소재가 갖고 있는 성질로서는 만들 수 없는 형태를 제시함으로써 사물에 새로운 질서를 부여하기도 한다.

헤르펀이 젊은 나이에 파리의 오뜨 꾸뛰르 컬렉션 에 참가하여 각광을 받으며 여러 신예 디자이너 중 에 두각을 나타낼 수 있었던 이유는 이처럼 디자인 형태에 내재되어 있는 심미적 독창성과 기술적인 차 별성이 독보적이고 특별하기 때문이다. 새로운 형태 의 창조는 곧 세계에 대하여 주체적인 의지와 탐험 적인 정신을 표명하는 것으로 시대의 유행을 뛰어 넘어 발굴되지 않은 창작의 영역을 향하여 도전하는 일이다. 따라서 진취적이고 도전적인 정신의 소유자 만이 조형적으로 특이한 디자인을 할 수 있다고 할 수 있는데 헤르펀은 이러한 실례를 잘 보여주었다고 할 수 있다.

헤르펀의 디자인에는 이와 같은 도전이 특이한 조 형 형태로 표현되어 있고, 논리와 일련성을 띠며 반 복되어 나타나기에 이러한 조형적 특이성을 헤르펀 의 스타일이라고 부를 수 있다.

지금까지 살펴본 바와 같이 스타일이 형성되기 위 한 필수 요소로서 <그림 $3>$ 에서처럼 심미적 독창성, 
기술적 차별성, 조형적 특이성이 동시적으로 수반되 어야 함을 이 연구를 통하여 알 수 있었다.

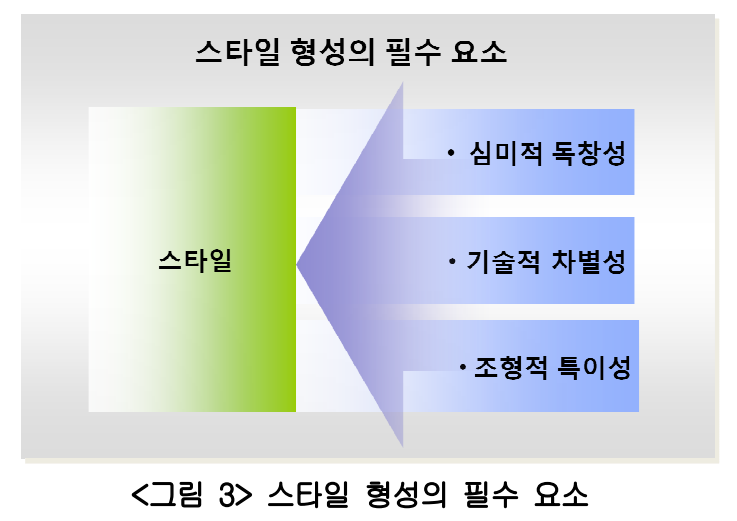

\section{V. 결 론}

세계 패션 시장의 무한 경쟁 속에서 신진 디자이 너가 성공할 수 있는 방법 중 하나는 창의적이고 기 억되는 새로운 디자인을 지속적으로 발표하여 자기 만의 스타일을 만들어내는 것이다. 수많은 유사성 속에서 드러나는 디자이너의 독특한 스타일은 세계 에 대한 자신의 기질을 드러내는 특색임과 동시에 시공간 속에서 구별되어 인식되는 코드와도 같은 것 으로 작용되며, 스타일이 확고히 드러나는 디자이너 는 사회가 부여하는 패션사적 의미를 갖게 되고 경 제적인 면에서도 특권적 위치를 갖게 된다.

헤르펀은 이처럼 디자이너의 스타일이 중요하게 부각되는 시대에, 오랜 역사적 전통과 기술, 막대한 자본을 앞세운 거대 기업이나 유명 디자이너에 대항 하며, 불과 6년이라는 짧은 기간 속에서 독창적인 스타일을 통하여 세계적인 신예 디자이너로 성장함 으로써 젊은 디자이너가 지향해야 할 방향과 창작성 의 중요성을 잘 보여주었다고 할 수 있다

따라서 이 논문에서는 창의적인 디자인을 지속적 으로 제시하며 독창적인 스타일로써 세계적인 명성 을 얻은 헤르펀의 스타일에 관하여 문헌적으로 고찰 하며 디자인을 분석하였다. 그리고 인간의 지각과 기억 체계를 다루는 정신생물학적 측면의 연구와 조
형적 측면에서의 분석을 병행하여 스타일의 의미와 형성 원인, 그리고 스타일 형성의 필수 요소는 무엇 인지 연구하였고, 그 결과 다음과 같은 결론을 도출 할 수 있었다.

첫째, 디자이너에게 있어서 스타일이란 어떤 특정 색상이나 소재, 형태, 창작 기법 등이 창작 과정 중 에 반복적으로 나타나는 디자이너의 독자적인 조형 적 특색을 의미한다. 그리고 스타일은 창작을 이끄 는 원동력으로서 작용되어 디자이너의 미적 관점, 제작 기법, 디자인 형태에 영향을 미치며, 한 번 형 성되기 시작되면 그 특색은 일관성을 갖고 지속되어 나타난다.

둘째, 스타일의 형성은 자기에게 관심이 있는 대 상만을 선택적으로 집중하는 선택적 주의집중, 대상 의 실재성을 자기의 용도에 맞게 주관적으로 지각하 며 다르게 해석하는 지각의 주관성, 외부로부터 수 용된 정보가 뉴런의 연결 특이성과 불변성 원리, 그 리고 뉴런 신호의 일방흐름 원리에 의해 고착화되는 장기 기억이 작용하기 때문에 가능하다.

영감을 주는 내용을 파악하는 일에서부터 그 내용 을 디자인으로 변화시키는 작업에는 항상 고착화된 장기 기억이 관여를 한다. 창작자에게 계열화되어 저장된 기억들이 창작 과정에서 상기되어 작업의 방 향을 조종하기 때문에 그 영향에 의해 디자이너가 어떤 소재, 색, 형태, 창작 기법을 다룬다 할지라도 결과물에는 항상 자기만의 독자적인 성향을 나타내 는 스타일이 드러나게 된다.

셋째, 디자이너의 스타일에는 자기만의 성격이나 특징을 한 부류로 한정시킬 수 있는 자기유사성이 현상되어 나타난다.

헤르펀은 졸업 작품 속에서 고전적인 의복구성 방 법을 통한 창작이 아니라, 평면적 패턴 구성에 의한 디자인을 최소화하고 그 대신에 소재를 엮거나 나 열, 또는 중첩시키고 늘어뜨려 인체를 장식하는 탈 패턴 창작 기법을 선보였다. 그 이후로도 일련의 소 재와 색상을 지속적으로 다루었고, 탈정형화를 통한 형태를 추구하며 공예적인 창작 기법에 의한 디자인 을 발표하여 자기유사성을 표현하고 있다. 이러한 창작 기법을 통하여 탄생된 조형 형태는 한 특색으 로 요약될 수 있었다. 
그리고 세계적으로 인정받는 스타일을 만들기 위 해서는 소재의 사용이나 제작 기법, 그리고 디자인 형태에 있어서 많은 것을 다양하게 다루는 다양성 보다는 어느 일정한 범주 안에서 창작되는 일관성이 필요함을 알 수 있었다.

넷째, 창작을 하는 디자이너에게 스타일이 형성되 기 위한 필수 요소는 '심미적 독창성', '기술적 차별 성', ‘조형적 특이성’이다.

'심미적 독창성'은 타인과 구별되는 심미안을 갖 고 자기의 창작 의도에 소용되는 소재를 선택적으로 관찰하여 독자적인 미적 관점으로 그 대상과 특별한 관계를 만들고, 거기에서 자기만이 표현할 수 있는 특별함을 구상하는 능력을 의미한다. '기술적 차별 성'은 디자인을 만들어 내는 과정 중에 드러나는 창 의적이고 독창적인 제작 기법의 유별함을 의미한다. '조형적 특이성'은 한 특색으로 요약될 수 있는 인 상적 형태가 일련성을 띠는 것으로서, 진취적이고 도전적인 정신에 의해 표현된 형태의 이질감을 나타 낸다. 그리고 '심미적 독창성'은 창작 과정 중에 지 속적으로 작용되는 스타일 형성의 근원적 요소로서 '기술적 차별성'과 ‘조형적 특이성'의 근간을 이룬다.

\section{참고문헌}

1) 자료검색일 2011. 08. 20. 자료출처 http:// www.irisvanherpen.com/site/collections/capri ole-paris-haute-couture-show

2) Henri Goelzer(1988), Dictionaire Latin, Paris: Editions Bodas, p.664.

3) 자료검색일 2012. 03. 09. 자료출처 http://fr.wiktionary.org/wiki/style

4) 김민수(1994), 모던 디자인 비평, 안그라픽스, p.31.

5) Ibid., p.35.

6) 이창배(2002), W.B.예이츠 연구, 동국대학교출 판부, p.339.

7) 김종철(1999), 시적 인간과 생태적 인간, 삼인, p.243.

8) 장석주(2006), 들뢰즈 카프카 김훈, 작가정신, p.155.

9) 김영선(2009), "지각과 기억에 의한 패션의 근 원적 현상에 관한 연구”, 홍익대학교 박사학위 논문, p.11 재인용, 이호우(2007), 대기행렬이 론, 시그마프레스, pp.522-523.

10) 김영선(2009), Ibid., p.12.

11) Ibid., p.12.

12) 박성봉(2001), 대중예술의 미학, 동연, p.264.

13) 프랭크 맥글러스키(2007), 소방관이 된 철학교 수, 이종철 역, 북섬, p.157.

14) 이창배(2002), op.cit., pp.448-449.

15) Eric R. Kandel, 기억을 찾아서, 전대호 역 (2009), 랜덤하우스, p.230.

16) E. Richard Nisbett(2009), 인텔리전스, 설선혜 역(2010), 김영사, p.57.

17) Ibid., p.230.

18) 김영선(2009), op.cit., pp.332-333 재인용, Rita Carter(2007), 뇌 맵핑마인드, 양영철, 이 양희 역, 말글빛냄, p.217.

19) 김영선(2009), Ibid., p.27.

20) 김영선(2009), Ibid., p.27 2차인용, Eric R. Kandel(2009), 기억을 찾아서, 전대호 역, 랜덤 하우스, p.136 재인용, James William(1890), The principles of psychology.

21) 김영선(2009), Ibid., p.28 재인용, Eric R. Kandel(2009), Ibid., p.345.

22) 김영선(2009), Ibid., pp.28-29 재인용, Eric R. Kandel(2009), lbid., p.92.

23) 김영선(2009), Ibid., p.35.

24) Ibid., p.35.

25) 김영선(2009), Ibid., p.35 재인용, Henri Bergson(1896), 물질과 기억, 박종원 역(2005), 아카넷, p.450.

26) Richard Senett(2008), 장인, 김홍식 역(2010), 21 세기북스, p.28.

27) 김영선(2009), op.cit., p.43 재인용, Eric R. Kandel(2009), op.cit., pp.139-140.

28) 김영선(2009), Ibid., p.43 재인용, Carter Rita(2007), op.cit., p.217.

29) 김영선(2009), Ibid., p.19, p.43 재인용, Eric 
R. Kandel(2009), op.cit., p.82, p.99.

30) 김영선(2009), Ibid., p.44.

31) Richard Senett(2008), op.cit., pp.26-27.

32) Eric R. Kandel(2009), op.cit., p.239.

33) 김영선(2009), op.cit., p.9.

34) 자료검색일 2011. 08. 20. 자료출처 http:// www.irisvanherpen.com/

35) 자료검색일 2011. 08. 14. 자료출처 http:// www.modearnhem.nl/

36) 자료검색일 2011. 08. 20. 자료출처 http:// www.irisvanherpen.com/

37) 자료검색일 2011. 08. 06. 자료출처 http:// www.vogue.fr/defiles/couture-hiver-2011-201 2-paris-iris-van-herpen/
38) 자료검색일 2012. 03. 11. 자료출처 http:// www.universalis.fr/encyclopedie/horatio -greenough/

39) 자료검색일 2012. 03. 20. 자료출처 http:// www.irisvanherpen.com/

40) 문광훈(2006), 아도르노와 김우창의 예술문화 론, 한길사, pp.399-400.

41) 김종철(1999), 시적 인간과 생태적 인간, 삼인, p.237.

42) 문광훈(2006), op.cit., p.400.

43) Mario Livio(2009), 신은 수학자인가?, 김정은 역(2009), 열린과학, p.346.

접수일(2012년 4월 16일),

수정일(1차 : 2012년 5월 7일, 2차 : 6월 5일),

게재확정일(2012년 6월 11일) 